\title{
GÊNESE, DESENVOLVIMENTO E INSTITUIÇÕES: COMPARANDO ALADI, MERCOSUL E UNASUL
}

\section{GENESIS, DEVELOPMENT AND INSTITUTIONS: COMPARING ALADI, MERCOSUL AND UNASUL}

\author{
Elisa de Sousa Ribeiro ${ }^{1}$ \\ Universidade de Brasília, Brasília, DF, Brasil \\ Edelcio Vigna ${ }^{2}$ \\ Universidade de Brasília, Brasília, DF, Brasil
}

\begin{abstract}
Resumo: O artigo objetiva estabelecer comparações entre Aladi, Mercosul e Unasul, instituições regionais de integração regional sul-americanas, com o propósito de explorar os níveis de democratização que cada instituição construiu, a partir das controvérsias entre os Estados Partes, que as integram, e das organizações da sociedade civil, que delas participam. O estudo ressalta o papel dos Estados nacionais nas relações multilaterais da região que, ao edificar os blocos econômicos, respondem às exigências da formação de um novo contexto econômico internacional e de uma nova fase de acumulação do capitalismo pelo capital financeiro.
\end{abstract}

Palavras-chaves: Aladi, Mercosul, Unasul, histórico, instituições.

\begin{abstract}
The article aims to establish comparisons between Aladi, Mercosur and Unasur, regional South American integration institutions, in order to explore the levels of democratization that each institution has constructed, based on the controversies between the States Parties that comprise them, and the civil society organizations that participate. The study highlights the role of national states in the multilateral relations of the region that, in building the economic blocs respond to the demands of the formation of a new international economic context and of a new phase of accumulation of capitalism by financial capital.
\end{abstract}

Keywords: Aladi, Mercosur, Unasur, history, institutions.

\footnotetext{
${ }^{1}$ Realizando Estágio Pós-doutoral no UNIEURO. Doutora e Mestre em Ciências Sociais pelo Centro de Pesquisa e Pós-Graduação Sobre as Américas da Universidade de Brasília (CEPPAC/UnB). Bacharel em Direito pelo UniCEUB. Advogada internacionalista. Professora no curso de Direito do UNIEURO. Professora no curso de Relações Internacionais do UniCEUB. Colíder do Grupo de Estudos do Mercosul do UniCEUB. Pesquisadora do Geomundo - Geografia Econômica Mundial da UTFPR. Coordenadora da obra "Direito do Mercosul". Coordenadora, juntamente com o Prof. Dr. Camilo Negri, da série de quatro volumes "Retratos sul-americanos: perspectivas brasileiras sobre história e política externa". Autora do livro "Mercosul: sobre Democracia e Instituições". E-mail: elisarib@gmail.com

2 Doutor em Ciências Sociais pelo Centro de Pesquisa e Pós-Graduação sobre as Américas (CEPPAC/UnB), vinculado ao Instituto de Ciências Sociais (ICS/UnB) da Universidade de Brasília (UnB), 2015. Mestre em Ciência Política pelo Instituto de Política da Universidade de Brasília (IPOL/UnB). Licenciado em História pela Faculdade de Filosofia, Ciências e Letras de Assis (UNESP). E-mail: edelcio.evo@gmail.com
} 


\section{INTRODUÇÃO}

O processo de globalização, pós II Guerra, alterou o mapa geopolítico mundial: a decadência dos países centrais; o surgimento União das Repúblicas Socialistas Soviéticas (URSS), que se opunha aos Estados Unidos (EUA), gerando, no âmbito das relações internacionais, a dicotomia capitalismo/socialismo; a posterior ascensão dos EUA como potência hegemônica; e a criação da Comunidade Europeia como uma coletividade de Estados em busca de melhor inserção nos mercados estrangeiros e manutenção da paz. A esse contexto, adiciona-se a construção dos blocos regionais sulamericanos, que muito se pautaram pelo processo de integração europeu.

Considerando as referidas modificações inseridas pelo processo de globalização, este artigo se desenvolverá em três seguimentos. Em primeiro lugar, serão comparados os momentos históricos em que ocorreu a criação da Associação LatinoAmericana de Integração (Aladi), do Mercado Comum do Sul (Mercosul) e da União de Nações Sul-Americanas (Unasul), na busca de apontar a sucessão de processos políticos que levaram a planificação das instituições. Serão apresentados, entre vários, três antecedentes de cada instituição, tendo em mente que apesar de terem influências diretas distintas todos, são parte de um mesmo processo de desenvolvimento das relações multilaterais na região. Em segundo lugar, serão abordadas as influências das teorias econômicas dominantes nas décadas de 1980 a 2000, na formação de blocos econômicos na América do Sul. Nessa seção, serão aludidos o Desenvolvimentismo, o Neoliberalismo e o Neodesenvolvimentismo. Em terceiro, analisar-se-á a influência da política externa dos Estados nacionais na coalização regional.

Uma preocupação que perpassará o texto é a de averiguar se há um nexo entre a ideologia vigente nos diversos períodos e os modelos de integração. Essa inquietação vai se verificar no primeiro capítulo, que aborda o surgimento das três instituições de integração criadas em momentos de convergência ideológica entre os governos dos Estados-Partes. O estudo buscará de padrões de arranjos no desenho institucional dos três organismos que serão expressos de forma visual e comparativa.

Da mesma forma, serão explorados os processos de tomada de decisão dentro dos três modelos de integração regional, com a finalidade de aferir as práticas comuns. Por fim, a solução de controvérsias, processo vital para o desenvolvimento equilibrado 
dos blocos regionais, será apreciada conforme parâmetros estabelecidos nos momentos analíticos posteriores.

\section{EMERGÊNCIA DOS BLOCOS REGIONAIS SUL-AMERICANOS}

Cada um dos blocos de integração analisados foi oriundo de diferentes processos políticos nacionais e regionais que levaram à sua criação. Há, em cada contexto, um avanço da base política e jurídica em relação a instituição antecessora. Nesse sentido, a Associação Latino-Americana de Integração antecedeu o Mercado Comum do Sul que, por seu turno, antecedeu à União de Nações Sul-Americanas.

A Aladi, por sua vez, teve como principais antecedentes as Conferências PanAmericanas, a Comissão Econômica para a América Latina e Caribe (Cepal), e a Associação Latino-Americana de Livre Comércio (Alalc). As Conferências PanAmericanas tiveram início em 1889 e foram um marco regional por meio do qual se discutiu a ideia de uma integração das Américas. Seu legado foi a aproximação entre os Estados nacionais e o início de um diálogo estratégico em busca de uma posição comum a fim de minimizar os processos beligerantes na região. Essas Conferencias demonstraram a necessidade de arquitetar um projeto de segurança regional e de se construir uma identidade comum entre os países. A ancestralidade colonial de origem ibérica foi o ponto seminal na formação de uma unidade nacional, que se contrapunha à exploração econômica, política e cultural europeia.

Cada bloco econômico se originou de um momento crítico da estrutura, da oportunidade política e da consciência continental. Os momentos não são lineares, mas busca-se retratá-los de forma lógica para facilitar a compreensão dos fatores que influenciariam o desenvolvimento das instituições em questão.

A Comissão Econômica para a América Latina e Caribe (Cepal), criada em 1948, com o objetivo de pensar o desenvolvimento da região de forma técnica e sistematizada, teve forte influência na formação de uma consciência latino-americana, de seu desenvolvimento e de revelar a sua dependência em relação aos países do norte. A teoria da dependência, desenvolvida pela Cepal, expõe de forma crítica não só o desnível da acumulação de capitais entre os países centrais industrializados e dos países periféricos agroexportadores, mas a necessidade de estabelecer outro paradigma que conduzisse a América Latina a "uma nova forma de inserção mundial a partir de uma redefinição das políticas internas. Esse paradigma será o nacional-desenvolvimentismo 
(...)" e "sua mais alta expressão e seu centro de difusão na Cepal" (Martins, 2011, p. 217). Essa corrente de pensamento influenciará a criação de foros de convergência econômica e comercial, como a Associação Latino-Americana de Livre Comércio (Alalc).

Em 1960, o Tratado de Montevidéu, instituiu a Alalc, cujo objetivo era estabelecer uma zona de livre comércio na América Latina, a fim de viabilizar reduções tarifárias e facilitar acordos de trocas comerciais entre seus integrantes. Conforme Raul Prebisch ressalta em seus textos, o excessivo fracionamento dos mercados tem sido um dos limites ao desenvolvimento técnico:

Já existe uma experiência suficiente para persuadir-se de que o comércio multilateral é o que mais convém ao desenvolvimento económico da América Latina. Poder vender e comprar nos melhores mercados respectivos, ainda que sejam diferentes, sem dividir o intercambio em compartimentos estanques, constitui a fórmula ideal. (Prebisch, 1986, p. 35).

A ampliação do comércio na região permitiria ampliar a economia de escala, fomentando a diversificação e o incremento das economias da região, diminuindo sua dependência em relação aos países "desenvolvidos". No entanto, o ciclo de ditaduras na América Latina (1960 a 1980), levou à formação da Operação Condor, que incorporou Argentina, Bolívia, Brasil, Chile, Paraguai, Peru e Uruguai, dificultando o fluxo econômico sub-regional. Este contexto, que coincidiu com o auge da Guerra Fria, praticamente inviabilizou o desenvolvimento da Alalc, modelo criado pelo segundo Tratado de Montevidéu, em 1980 (TM80).

As diferenças de interesses econômicos de apropriação de mercados entre os países, assim como a interferência dos Estados Unidos, mantiveram-se na mesa de negociação durante todo o processo de construção de instituições de integração regional. Buscou-se, então, criar um novo organismo para substituir a Alalc, que pudesse superar os desafios colocados aos países da região e não resolvidos. O caminho foi adotar um modelo que viabilizasse de forma mais efetiva os objetivos comuns formulados entre os Estados. Assim, o TM80 criou a Associação Latino-Americana de Integração (Aladi), que herdou da Alalc, seus mecanismos, instituições e muitos de seus defeitos ou insuficiências.

Na década de 1980, o diálogo entre a Argentina e o Brasil foi frutífero e resultou na ratificação de alguns acordos bilaterais. Pode-se destacar o Programa de Integração e Cooperação Econômica (PICE), que previa uma progressiva liberação do 
comércio bilateral, e subscreveram a Ata de Iguaçu, que firma o interesse em avançar em conjunto rumo a uma integração econômica e comercial. Foi instituída, também, uma série de compromissos bilaterais, como a Ata para a Integração ArgentinoBrasileira; a Declaração Conjunta sobre Política Nuclear, e o Tratado de Integração, Cooperação e Desenvolvimento. Esses acordos regionais passaram a compor o arcabouço político-jurídico, que foi a base sobre a qual se assentou o Tratado de Assunção (1991), que incorporou o Uruguai e o Paraguai e constituiu o Mercado Comum do Sul (Mercosul). Esse processo de integração, evoluiu com a criação de instituições regionais (a partir de concessões entre as partes) e com o enfrentando às investidas estadunidenses, que não se apartaram da ideia do "Destino Manifesto".

[...] na maneira como outras nações [Inglaterra e França] se comprometeram a se intrometer, entre nós e as partes adequadas [EUA-Texas ${ }^{3} /$ México] no caso, num espírito de interferência hostil contra nós, pelo objeto declarado de frustrar nossa política e dificultar nosso poder, limitando nossa grandeza e o cumprimento de nosso destino manifesto para espalhar o continente atribuído pela Providência para o livre desenvolvimento de nossa raça que se multiplica aos milhões anualmente (O'Sullivan, 1845, p.2 - grifo nosso).

A institucionalização do Mercosul foi, e ainda é, um a construção mal digerida pelos EUA, tanto que propuseram o estabelecimento da Área de Livre Comércio das Américas (Alca), rejeitada pelos países da região em 2005. Em 2012, os EUA estimularam a criação da Aliança para o Pacífico (AP) - composta de países aliados por meio de tratados de livre comércio. Os países do Mercosul se recusaram a participar da AP, porém o Brasil e a Argentina, após da "revirada conservadora", dos meados da segunda década do século XXI, defendem uma maior integração latino-americana objetivando, inclusive, negociações, com a Aliança para o Pacífico (G1.Globo, 2017).

Além das instituições voltadas ao campo comercial, os governos sulamericanos se preocuparam em estabelecer uma organização regional que tivesse como objetivo o equilíbrio político do continente. O trajeto histórico desde a Aladi até a institucionalização da Unasul foi conduzida pelo Grupo de Contadora e o Grupo Apoio à Contadora, cujo objeto era a coordenação de ações para o enfrentamento comum dos problemas da América Latina. Em 1990, os grupos se aglutinaram no Grupo dos Oito, que em seguida foi denominado de Grupo do Rio. Esse último, formou a base de

\footnotetext{
${ }^{3}$ Em 1837, a República do Texas, que tinha conquistado a sua independência do México, votou a favor da anexação com o consentimento dos EUA.
} 
diálogo entre os países da região, que se ampliaria de forma a estabelecer um laço que resultaria na criação e institucionalização de uma reunião periódica de presidentes.

A I Reunião de Presidentes da América do Sul, em 2000, objetivou de promover o desenvolvimento integrado da infraestrutura de transporte, energia e telecomunicações dos seus países. Esse foi o primeiro passo rumo a uma maior coordenação comum dos países da América do Sul, haja vista que o foro se estabeleceu de forma a coordenar ações de nível intra e extra regionais. Em uma das reuniões, foi criada a Iniciativa para a Integração da Infraestrutura Regional Sul-Americana (IIRSA), organismo que atuou no sentido de colocar em marcha os objetivos de integração na área da infraestrutura.

Em 2004, durante a III Reunião de Presidentes da América do Sul, foi criada a Comunidade Sul-Americana de Nações (CASA), que tinha como finalidade ser o organismo de concertação política entre os Estados do subcontinente. Em 2007, durante a reunião na Isla Margarita, a designação CASA/CSN foi substituída por União de Nações Sul-Americanas (Unasul). Em 2008, foi assinado o Tratado Constitutivo da Unasul, que prevê uma convergência entre a Comunidade Andina (CAN) e o Mercosul, para a formação de um mercado econômico sul-americano.

Os mencionados foros e organismos regionais sul-americanos expressam o curso institucional no qual as preocupações e os interesses dos Estados nacionais percorreram e que foram, paulatinamente, se consolidando, criando normas, acordos e tratados, nos quais sobressaem compromissos históricos e conjunturais, que marcam de forma menos instável a relação dos países sul-americanos.

Para além da construção progressiva da integração regional sul-americana, das suas sedes e desenvolvimento das suas ações que promoveram uma aproximação entre os países da região, cabe, em seguida, observar em quais pressupostos teóricos cada uma das três organizações se baseou.

\section{INFLUÊNCIAS TEÓRICAS}

Cada uma das experiências de integração citadas foi influenciada por uma teoria econômica diferente, haja vista os períodos em que foram criadas. A Aladi teve como base teórica o desenvolvimentismo cepalino; o Mercosul foi criado em um contexto neoliberal; e a Unasul, em um processo de estabelecimento do 
neodesenvolvimentismo ${ }^{4}$. Os modelos teóricos expressam uma condição dominante, mas não hegemônica no período de sua existência, pois os paradigmas convivem e disputam durante um largo tempo a legitimação de seus pressupostos, até que o amalgama desses encontre um novo padrão, que ao entrar no embate venha resignificar os mais antigos. A figura 01 demonstra, sem os matizes necessários, o encadeamento das teorias econômicas, mas é preciso pressupor as junções que foram sendo realizadas nas passagens de um padrão para outro.

Figura 1- Organizações regionais e teorias econômicas

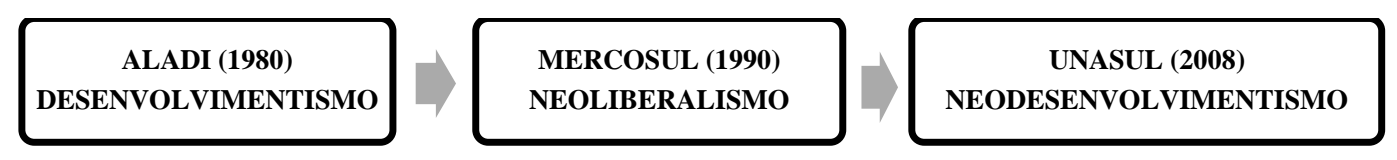

Fonte: Ribeiro, 2016.

As ideias desenvolvimentistas sustentadas pela Cepal baseavam-se em quatro pilares: (1) a dependência da periferia em relação ao centro; (2) a deterioração dos termos de troca; (3) a industrialização por substituição de importações; (4) e a integração econômica regional (Ribeiro; Pinchemel, 2011). Os anos de 1960 até 1980 foram marcados pelo desenvolvimentismo, que de início foi sustentado por empréstimos externos com a finalidade de apoiar os projetos de ampliação econômica, com enfoque no processo de substituição de importações por meio da industrialização nacional e formação de um mercado interno de consumo. Porém, na década de 1970 o crescimento da dívida externa chegava ao limite da poupança pública, que começou a esgotar-se rapidamente. Ocorria, em toda América Latina uma "estatização" da dívida externa que era uma forma perversa de financiamento do déficit público, que cada vez maior se transformou em crise fiscal do Estado. De acordo com Bresser-Pereira,

A crise latino-americana que então explodiu era essencialmente consequência de duas decisões tomadas no início dos anos 70: pelo lado da América Latina, a decisão de continuar com uma estratégia de crescimento e com um modo de intervenção estatal (a substituição de importações) que não mais funcionavam; pelo lado dos países credores, a decisão de financiar essa estratégia, assegurando assim sua sobrevida artificial (Bresser-Pereira, 1993, p. 41).

\footnotetext{
4 “O neodesenvolvimentismo vê a redução das desigualdades sociais e o combate ao pauperismo por um viés economicista, de geração de renda nas camadas pobres voltada para a formação de um mercado de massas. O objetivo é gerar uma base econômica de venda interna das mercadorias, portanto, de realização da mais-valia. [...]. Ou seja, o mercado é tido pelo neodesenvolvimentismo como o principal meio de melhorar o bem-estar da população, com uma ação auxiliar do Estado no alívio da extrema pobreza e outras expressões mais agudas da questão social" (Raichelis, 2014, p. 590).
} 
Nesse contexto foi criada a Alalc, que foi substituída pela Aladi $^{5}$, com modificações relevantes no formato de promoção dos acordos bilaterais e multilaterais.

Os anos de 1980, denominados controversamente de "década perdida", apresentaram uma dualidade analítica. De um lado encontrava-se a crise da dívida externa, a alta inflação, a diminuição dos investimentos externos nos países da região e, consequente, diminuição do investimento nacional, que caracterizava as observações economicistas; e de outro lado, verificava-se uma ebulição da sociedade civil, a emergência das organizações não-governamentais, entre outros movimentos identitários. O avanço do processo social não foi suficiente para impedir o domínio do econômico, por meio da implementação de uma série de políticas públicas neoliberais por diversos governos sul-americanos. Esse período polêmico marcou a transição do desenvolvimentismo ao neoliberalismo.

Dentro do modelo neoliberal, no âmbito do denominado regionalismo aberto ${ }^{6}$, Brasil e Argentina firmaram acordos bilaterais, que serviram de base política e jurídica para o Tratado de Assunção (1991) que, com a adesão do Paraguai e do Uruguai, criou o Mercosul. O desenho institucional do bloco pressupõe negociações intragovernamentais com concessão de poucos espaços para a participação social, na medida em que o órgão supremo do Mercosul, o Conselho do Mercado Comum (CMC), é formado primordialmente pelos Ministérios das Relações Exteriores, Ministérios da Economia e Bancos Centrais (Ribeiro, 2012).

No final de agosto de 2000, foi realizada a Cúpula de Brasília, também denominada I Reunião de Presidentes da América do Sul contou pela primeira vez, com a presença de todos os Chefes de Estado da região. Nessa Cúpula, foi criada a base para a cooperação Sul-Sul e decidido ações para valorizar o território e o mercado sulamericano, em um contexto autóctone. Nos anos que se seguiram, a coordenação entre

\footnotetext{
${ }^{5}$ O fracasso da ALALC foi ocasionado por vários fatores: o processo de substituição de importações continuou forte, ao contrário do que previa a proposta de industrialização da CEPAL; a formação do Grupo Andino que queriam acelerar o processo; desigualdade econômica entre os países; processo de integração não cumpriu a função anticíclica, entre outros. A ALALC não se constituiu em uma zona de livre comércio, foi apenas uma zona de preferências comerciais de caráter limitado (Dathein, 2005, p.06). ${ }^{6}$ No item 20 da publicação Cinquenta anos de pensamento na CEPAL (v.2) encontra-se a concepção cepalina de "regionalismo aberto": "20. Neste documento, denomina-se "regionalismo aberto" o processo que surge ao serem conciliados os dois fenômenos descritos nos parágrafos anteriores: a interdependência nascida de acordos especiais de caráter preferencial e a que é basicamente impulsionada pelos sinais do mercado, resultantes da liberalização comercial em geral. O que se busca com o regionalismo aberto é que as políticas explícitas de integração sejam compatíveis com as políticas tendentes a elevar a competitividade internacional, além de complementares a elas" (Bielschowsky, 2000, p. 945).
} 
os países foi se aprimorando, em razão da identificação ideológica de espectro progressista dos Chefes de Estado da região. Esse "giro à esquerda" propiciou um ambiente político que se buscou limitar as políticas neoliberais e oportunizou a emergência do paradigma neodesenvolvimentista.

A condição dominante do neodesenvolvimentismo não necessita, necessariamente, para se instituir, de um governo progressista. Ao contrário, esse modelo econômico se adapta melhor se as diretrizes políticas se pautarem em um espectro conservador. Dessa forma, os preceitos políticos vão se contrapor durante o tempo em que a integração vai se maturando. Segue-se um esboço das influências de cunho político-ideológico que marcaram o desenvolvimento de cada bloco.

\section{INFLUÊNCIAS POLÍTICAS}

A Aladi, o Mercosul e a Unasul foram criados em diferentes momentos da história política da região. A categorização do espectro ideológico dos partidos sulamericanos tem sido pesquisada a partir de diversas metodologias, mas não há um consenso entre os cientistas políticos sobre a linha fronteiriça que separa as posições de esquerda e direita.

[...] o conteúdo das categorias de esquerda e direita mudou consideravelmente ao longo do tempo. Entretanto, o significado que vincula a defesa da igualdade social, herdeira de princípios socialistas, com a esquerda, e a defesa do livre mercado capitalista com a direita parece ter sobrevivido aos rearranjos mundiais do final do século XX (Tarouco e Madeira, 2013, p.151).

O cientista político Norberto Bobbio confirma a assertiva de Tarouco e Madeira ao afirmar que "direita e esquerda são termos antitéticos que há mais de dois séculos têm sido habitualmente empregados para designar o contraste entre as ideologias e entre os movimentos [...] do pensamento e das ações políticas" (Bobbio, 1994, p.31). Essa terminologia, que surgiu durante a Revolução Francesa, se mantém atual no debate contemporâneo sobre as formas de interpretar e de se inserir no mundo.

Esquerda e direita não indicam apenas ideologias. Reduzí-las a pura expressão do pensamento ideológico seria uma indevida simplificação. Esquerda e direita indicam programas contrapostos com relação a diversos problemas cuja solução pertence habitualmente à ação política, contrastes não só ideias, mas também de interesses e de valorações a respeito da dieção a ser seguida pela sociedade, contrastes que existem em toda sociedade e que não vejo como possam simplesmente desaparecer (Bobbio, 1994, p. 33 e 34). 
O cientista social Bresser-Pereira considera que a esquerda e a direita, no campo político, se batem pelo poder e, neste embate, disputam as forças centristas para poder acessar ao poder de governar com maioria nos centros de decisão. Para isso dialogam e refazem seus projetos em busca de um consenso que lhes permita implementar seus empreendimentos e propósitos.

Vejo o "centro político" apenas como ponto de referência no espectro político: indivíduos e partidos políticos estarão ou à esquerda ou à direita desse centro. Não há partidos ou indivíduos de centro nas sociedades capitalistas. O máximo que podemos afirmar é que há uma centro-esquerda e uma centro-direita. (...). Políticos à esquerda e à direita sabem que devem lutar para controlar o centro. E sabem também que esse centro está em contínua mutação, de forma que, se forem capazes de ver o novo centro, saberão também fazer as necessárias mudanças nos programas e estratégias dos partidos políticos (Bresser-Pereira, 2000, p.145).

Considerando o debate sobre direita/esquerda e suas significações nos variados campos de poder, é preferível neste artigo evitar a pura dicotomia e reflexionar sobre a terminologia "conservadores" e "progressistas", mesmo entendendo as críticas de Bobbio e as críticas que podem originar desta preferência. Ao utilizar esta terminologia adota-se o modelo do Terceiro Inclusivo e não o Terceiro Incluído. De acordo com Bobbio, o último impede que os termos direita/esquerda entrem em choque e cria uma terceira solução, enquanto o Terceiro Inclusivo busca integrar os termos em uma síntese superior, "faz deles duas partes de um todo, de uma totalidade dialética" (Bobbio, 1994, p. 38). Observando essas considerações, é possível afirmar que a Aladi e o Mercosul foram criados por governos mais inclinados à esfera política conservadora, e a Unasul foi criada por governos mais próximos ao campo progressista.

Figura 2- Organizações regionais e posições políticas

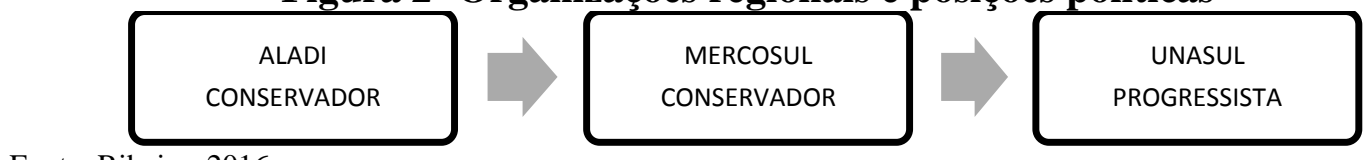

Fonte: Ribeiro, 2016.

Desde os anos de 1960, as políticas externas executadas pelos países sulamericanos sofreram forte influência dos governos militares que, apoiados pelos Estados Unidos, opunham-se ao comunismo e ao socialismo e, ao mesmo tempo, incorporam os vícios existentes nas relações entre o poder militar e a elite estadunidense. 
Elisa Ribeiro

Edelcio Vigna

Nas relações entre o poder militar dos EUA e as elites políticomilitares latino-americanas, reproduzia-se uma situação semelhante àquela que, no interior da superpotência, conectava os poderes militar e civil com o Estado, ou seja, a cooptação, trafico de influencias, corrupção, oportunidades de enriquecimento ou ascensão política, de troca que acompanhava o mecanismo de convencimento ideológico efetuado pelo binômio Doutrina de Segurança Nacional e American Way of Life (Padrós, 2005, p. 182).

Os efeitos das influências dos EUA continuaram a se reproduzir na década de 1980, durante o período de redemocratização. O que se verificou foi um deslocamento da questão da segurança nacional e continental para a questão da construção do mercado regional. A Associação Latino-Americana de Integração, desenhada nesse contexto, demonstra nas funções de seus órgãos a preocupação somente com assuntos de cunho econômico e comercial, não estando consagradas questões de segurança social. A integração regional, em resposta ao processo de globalização, emerge como um modelo direcionado a ampliar a economia de escala para a promoção do desenvolvimento econômico, crescimento da indústria nacional e incremento do processo de substituição de importações.

O Consenso de Washington (1989) recomendou aos governos centro e sulamericanos a implementação de políticas neoliberais que se pautassem pela abertura econômica e comercial, a adoção da economia de mercado e controle fiscal macroeconômico. Durante três décadas, os governos conservadores seguiram os ditames do neoliberalismo, porém, os efeitos negativos dessas políticas levaram os governos a repensar as suas diretrizes socioeconômicas. Nos anos 2000, a tônica do discurso neoliberal e integracionista mudou, passando a abarcar não somente assuntos de natureza econômica e comercial, mas também sociopolítico. Nesse contexto, a estrutura do Mercosul se diversificou para se ajustar à nova faceta da integração.

A mudança no cenário regional possibilitou a criação da Unasul, como um bloco de integração exclusivamente sul-americano, que abarcou temas de interesse comum da região voltados para o desenvolvimento de infraestruturas, melhoria da dimensão social, diálogo político para alcance de consensos e defesa da democracia.

Nesse novo quadro, esperava-se que a estrutura institucional espelhasse esse novo momento, no entanto as arenas decisórias da continuaram a ser operacionalizadas por um conselho intraestatal, com pouca transparência em suas decisões e mínimo espaço para a participação da sociedade civil. Somente em um segundo momento, foram criados conselhos temáticos, que possibilitaram o envolvimentos das organizações e 
movimentos sociais nos processos de debates das políticas regionais, cujas ratificações dependem do deferimento do Conselho de Chefas e Chefes de Estado e de Governo, que é o órgão máximo da Unasul.

O desenho institucional dos blocos regionais em análise é tão importante para as decisões como são os interesses político-econômicos dos Estados parte ou os pressupostos teóricos e políticos fundantes de cada organismo sul-americano. A conjuntura sul-americana possibilitou a oportunidade para que os Estados chegassem a consensos que em outros períodos não seria possível em razão dos conflitos históricos existentes entre as diversas Nações. A estrutura de poder, que se espelha no organograma da Unasul, pode, inclusive, antecipar a tramitação, o debate e a aprovação de uma ou outra proposição. Em razão disso, é importante uma breve análise comparativa entre os desenhos institucionais da Aladi, do Mercosul e da Unasul.

\section{DESENHO INSTITUCIONAL}

As estruturas institucionais da Aladi, do Mercosul e da Unasul, são construções históricas, ou seja, criadas sob condições sociais, econômicas e políticas existentes à sua época. Por isso, a organização dessas instituições responde e reflete os interesses dos Estados e de suas elites nas suas relações de poder, no âmbito do processo de desenvolvimento do capitalismo financeiro contemporâneo. Não obstante, há uma configuração similar entre os três organismos regionais, no que tange aos processos decisórios.

Com vistas a realizar uma análise concisa dos seus órgãos, pode-se partir de um esboço que represente cada instituição colocando em relevo seus principais órgãos de decisão. .

Figura 3- Organizações regionais e seus órgãos de decisão

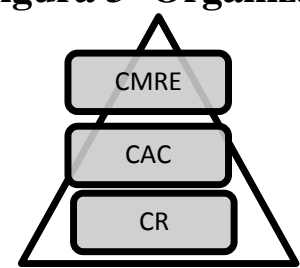

ALADI

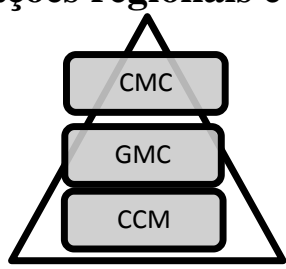

MERCOSUL

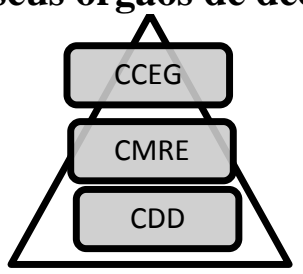

UNASUL

Fontes: Tratado de Montevidéu de 1980, Tratado de Assunção, Protocolo de Ouro Preto e Tratado Constitutivo da Unasul. Elaboração: Ribeiro, 2016. 
As atribuições dos órgãos, designados como os decisórios, vai além das que estão registradas, mas preferiu-se citar as mais importantes compreendendo que quem pode mais, pode menos. Os comitês mais acima, por exemplo, têm maior poder de decisão dos que estão hierarquicamente abaixo e, assim, sucessivamente, como se pode constatar no Tratado Constitutivo da União de Nações Sul-Americanas.

No topo das pirâmides encontram-se os órgãos a quem competem as deliberações dos blocos: Conselho de Ministros das Relações Exteriores (CMRE/ Aladi), competente para adotar regras gerais referentes ao desenvolvimento do processo de integração; Conselho do Mercado Comum (CMC/Mercosul), órgão supremo do bloco e tem como função conduzir a política do processo de integração; e o Conselho de Chefas e Chefes de Estado e de Governo (CCEG/Unasul), encarregado do estabelecimento de diretrizes políticas, planos de ação, programas e projetos.

No segundo nível estão a Conferência de Avaliação e Convergência (CAC/ Aladi), cuja competência inclui examinar o funcionamento do processo de integração e a convergência dos acordos de alcance parcial; o Grupo Mercado Comum (GMC/Mercosul), que apresenta os projetos de Decisão ao CMC e se responsabiliza pela tomada de providências necessárias ao cumprimento das Decisões; e o Conselho de Ministras e Ministros de Relações Exteriores (CMRE/Unasul), competente para adotar Resoluções, que visem implementar as Decisões do CCEG.

No terceiro nível encontram-se o Comitê de Representantes (CR/Aladi), a quem compete promover a celebração de acordos de alcance regional; a Comissão de Comércio do Mercosul (CCM/Mercosul), cuja função principal é zelar pela relação comercial intra-Mercosul e com terceiros países, organismos internacionais e acordos de comércio; e o Conselho de Delegados e Delegadas (CDD/Unasul), encarregado de implementar as Decisões do CCEG e as Resoluções do CMRE.

Independentemente do critério adotado para analisar e organizar essas instituições e órgãos nota-se que o processo de integração na América do Sul é protagonizado, em grande parte, pelos Ministérios das Relações Exteriores e, em seguida, pelas pastas responsáveis pelo comércio, desenvolvimento e agropecuária dos Estados Partes. Dessa forma, pode-se reinterpretar o desenho das pirâmides da seguinte forma:

Figura 4- Organizações regionais e órgãos de decisão 
Elisa Ribeiro

Edelcio Vigna

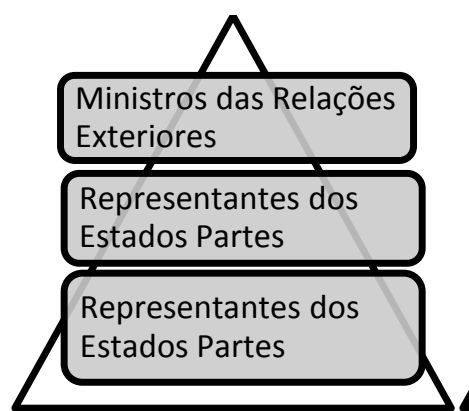

ALADI

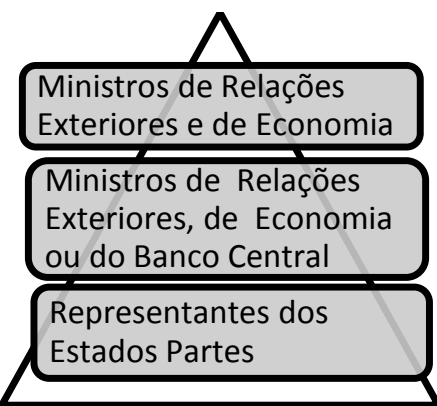

MERCOSUL

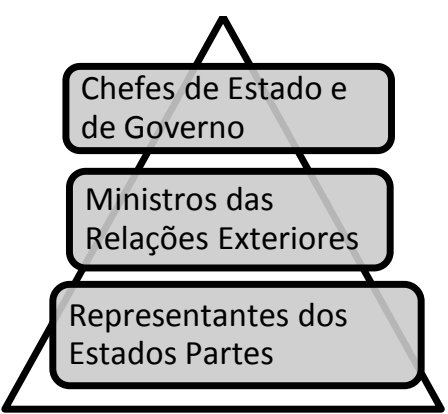

UNASUL

Fontes: Tratado de Montevidéu de 1980, Tratado de Assunção, Protocolo de Ouro Preto e Tratado Constitutivo da Unasul. Elaboração: Ribeiro, 2016.

$\mathrm{Na}$ figura 4 transparece a falta de espaço para a atuação da sociedade civil no processo de integração regional. Esse desenho expressa o déficit democrático existente nas instituições regionais, que não consideram as posições das organizações e movimentos sociais como pertinentes para que as negociações possam ser concebidas com justiça social (Ribeiro, 2012). Os atores estatais que integram os foros regionais são indicados, por meio de negociações internas, pelos governos sem que as sociedades civis sejam sequer consultadas. Assim, representam os interesses governamentais que necessariamente podem não coincidir com as necessidades da sociedade civil.

As estruturas descritas na figura 4 têm sido objeto de análise por diversos autores, com vistas a classificá-los. As análises de Adriana Dreyzin, Deisy Ventura e Roberto Labrano, apresentam distintos critérios de classificação dos órgãos do bloco.

Adriana Dreyzin (2005, p. 647), assim como outros pesquisadores, classifica a competência dos órgãos entre: (1) capacidade decisória; (2) de capacidade consultiva; e (3) capacidade técnica. Para os fins desta pesquisa, entendemos que "capacidade decisória" se aplica ao órgão que tem força de criar um compromisso oponível aos membros do bloco; "capacidade consultiva", órgão que tem poder de proposição e capacidade técnica, órgãos formados por tecnocratas; "capacidade técnica" requer qualificação técnica e operacional de um órgão em relação aos outros.

É reconhecido que toda tipologia deixa de expressar as zonas cinzentas entre um e outro arquétipo. Dessa maneira, explicam-se porque alguns órgãos das instituições de integração se encaixarem em mais de uma figura do que em outras. Ainda assim, optou-se por aceitar uma classificação a partir do perfil dominante do órgão. Nesse sentido, pode-se afirmar que, de acordo com a classificação de Dreyzin (2005, p. 647): 
Quadro 1- Organizações regionais e sua estrutura institucional

\begin{tabular}{|c|c|c|c|}
\hline & DECISÓRIO & CONSULTIVO & TÉCNICO \\
\hline 蛋 & $\begin{array}{l}\text { Conselho de Ministros das } \\
\text { Relações Exteriores }\end{array}$ & Comitê de Representantes & $\begin{array}{l}\text { Conferência de Avaliação e } \\
\text { Convergência }\end{array}$ \\
\hline \multirow{5}{*}{ 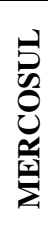 } & Conselho do Mercado Comum & Alto Representante-Geral & Subgrupos de Trabalho \\
\hline & Grupo Mercado Comum & CRPM & Comitês Técnicos \\
\hline & Comissão de Comércio & Parlamento & FOCEM \\
\hline & FCES & Reuniões de Ministros & Secretaria \\
\hline & TPR & Reuniões Especializadas & Grupos \\
\hline \multirow{5}{*}{ 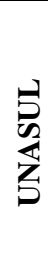 } & \multirow[t]{5}{*}{$\begin{array}{l}\text { Conselho de Chefas e Chefes } \\
\text { de Estado e de Governo }\end{array}$} & \multirow{5}{*}{$\begin{array}{l}\text { Conselho de Ministras e } \\
\text { Ministros das Relações } \\
\text { Exteriores }\end{array}$} & $\begin{array}{l}\text { Conselho de Delegadas e } \\
\text { Delegados }\end{array}$ \\
\hline & & & Secretaria-Geral \\
\hline & & & Conselhos Ministeriais \\
\hline & & & Grupos de Trabalho \\
\hline & & & Órgãos auxiliares \\
\hline
\end{tabular}

Fonte: DREYZIN, 2005, p. 647. Elaboração: Ribeiro, 2016.

Deisy Ventura (2003, p. 85-97 e 111-126) separa os órgãos em: (1) deliberativos; (2) consultivos ou administrativos; (3) função normativa; (4) função de controle; (5) função internacional. Para os nossos fins, entenderemos como "órgãos deliberativos" aqueles formados por colegiado; por "consultivos e administrativos", aqueles tem poder de proposição e de acompanhamento do processo de integração; por "função normativa", órgãos que criam compromissos aos Estados Partes; por "função de controle", aqueles que emitem recomendações aos órgãos superiores ou emitem pareceres; e por "função internacional", aqueles que detêm capacidade jurídica para representar o organismo diante de terceiros.

Ao considerar a diferenciação realizada por Ventura (2003, p. 85-97 e 111126), pode-se classificar os órgãos de acordo com o Quadro 2.

Quadro 2- Organizações regionais seus órgãos de decisão

\begin{tabular}{|c|c|c|c|c|}
\hline & DELIBERATIVO & $\begin{array}{l}\text { CONSULTIVO OU } \\
\text { ADMINISTRATIVO }\end{array}$ & $\begin{array}{l}\text { FUNÇÃO DE } \\
\text { CONTROLE }\end{array}$ & $\begin{array}{c}\text { FUNÇÃO } \\
\text { INTERNACIO } \\
\text { NAL }\end{array}$ \\
\hline \multirow{3}{*}{ 安 } & $\begin{array}{l}\text { Conselho de } \\
\text { Ministros das } \\
\text { Relações Exteriores }\end{array}$ & & & \\
\hline & $\begin{array}{l}\text { Comitê de } \\
\text { Representantes }\end{array}$ & $\begin{array}{l}\text { Comitê de } \\
\text { Representantes }\end{array}$ & $\begin{array}{l}\text { Comitê de } \\
\text { Representantes }\end{array}$ & $\begin{array}{l}\text { Comitê de } \\
\text { Representantes }\end{array}$ \\
\hline & $\begin{array}{l}\text { Conferência de } \\
\text { Avaliação e } \\
\text { Convergência }\end{array}$ & $\begin{array}{l}\text { Conferência de } \\
\text { Avaliação e } \\
\text { Convergência }\end{array}$ & & \\
\hline$\sum \frac{0}{I I}$ & $\begin{array}{l}\text { Conselho do } \\
\text { Mercado Comum }\end{array}$ & & $\begin{array}{l}\text { Comissão de } \\
\text { Comércio }\end{array}$ & $\begin{array}{l}\text { Conselho do } \\
\text { Mercado }\end{array}$ \\
\hline
\end{tabular}




\begin{tabular}{|c|c|c|c|c|}
\hline & & & & Comum \\
\hline & $\begin{array}{l}\text { Grupo Mercado } \\
\text { Comum }\end{array}$ & & $\begin{array}{l}\text { Grupo Mercado } \\
\text { Comum }\end{array}$ & $\begin{array}{l}\text { Grupo Mercado } \\
\text { Comum }\end{array}$ \\
\hline & $\begin{array}{l}\text { Comissão de } \\
\text { Comércio }\end{array}$ & & & $\begin{array}{l}\text { Comissão de } \\
\text { Comércio }\end{array}$ \\
\hline & TPR & & & \\
\hline & $\begin{array}{l}\text { Foro Consultivo } \\
\text { Econômico-Social }\end{array}$ & $\begin{array}{l}\text { Comissão de } \\
\text { Representantes } \\
\text { Permanentes }\end{array}$ & & \\
\hline & Parlamento & Parlamento & & \\
\hline & , & $\begin{array}{l}\text { Alto Representante- } \\
\text { Geral }\end{array}$ & & \\
\hline & & Reuniões de Ministros & & \\
\hline & & $\begin{array}{l}\text { Reuniões } \\
\text { Especializadas }\end{array}$ & & \\
\hline & & Secretaria & Secretaria & \\
\hline & $\begin{array}{l}\text { Conselho de Chefas } \\
\text { e Chefes de Estado } \\
\text { e de Governo }\end{array}$ & & & $\begin{array}{l}\text { Conselho de } \\
\text { Chefas e Chefes } \\
\text { de Estado e de } \\
\text { Governo }\end{array}$ \\
\hline & Conselho de & & Conselho de & Conselho de \\
\hline & Ministras e & & Ministras e & Ministras e \\
\hline & Ministros de & & Ministros de & Ministros de \\
\hline 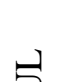 & Relações Exteriores & & Relações Exteriores & $\begin{array}{l}\text { Relações } \\
\text { Exteriores. }\end{array}$ \\
\hline 点 & $\begin{array}{l}\text { Conselho de } \\
\text { Delegados e } \\
\text { Delegadas } \\
\end{array}$ & & $\begin{array}{l}\text { Conselho de } \\
\text { Delegados e } \\
\text { Delegadas }\end{array}$ & \\
\hline & $\begin{array}{l}\text { Reuniões } \\
\text { Ministeriais } \\
\text { Setoriais }\end{array}$ & $\begin{array}{l}\text { Reuniões Ministeriais } \\
\text { Setoriais }\end{array}$ & & \\
\hline & $\begin{array}{l}\text { Conselhos de nível } \\
\text { Ministerial }\end{array}$ & $\begin{array}{l}\text { Conselhos de nível } \\
\text { Ministerial }\end{array}$ & & \\
\hline & Grupos de Trabalho & Grupos de Trabalho & & \\
\hline & & & Secretaria-Geral. & Secretaria-Geral \\
\hline
\end{tabular}

Fonte: VENTURA, 2003, p. 85-97 e 111-126. Elaboração: Ribeiro, 2016.

Conforme a classificação de Roberto Labrano (1998, p. 125-127), pode-se separar os órgãos entre políticos e técnicos.

Quadro 3- Organizações regionais e seus órgãos políticos e técnicos

\begin{tabular}{|c|c|c|}
\hline & ÓRGÃOS POLÍTICOS & ÓRGÃOS TÉCNICOS \\
\hline \multirow{2}{*}{$\begin{array}{l}\text { 安 } \\
\text { 安 }\end{array}$} & Conselho de Ministros das Relações Exteriores & Comitê de Representantes \\
\hline & Conferência de Avaliação e Convergência & Secretaria-Geral \\
\hline \multirow{4}{*}{$\begin{array}{l}\tilde{y} \\
0 \\
\frac{z}{y} \\
\frac{1}{\Sigma}\end{array}$} & Conselho do Mercado Comum & Comissão de Comércio \\
\hline & Grupo Mercado Comum & Tribunal Permanente de Revisão \\
\hline & Foro Consultivo Econômico-Social & Secretaria Administrativa \\
\hline & Parlamento do Mercosul & FOCEM \\
\hline
\end{tabular}




\begin{tabular}{|l|l|l|}
\hline & Alto-Representante & \\
\hline \multirow{3}{S}{} & $\begin{array}{l}\text { Conselho de Chefas e Chefes de Estado e de } \\
\text { Governo }\end{array}$ & $\begin{array}{l}\text { Conselho de Delegadas e } \\
\text { Delegados }\end{array}$ \\
\cline { 2 - 4 } & $\begin{array}{l}\text { Conselho de Ministras e Ministros das Relações } \\
\text { Exteriores }\end{array}$ & Secretaria-Geral \\
\hline \multirow{S}{S}{} & \\
\hline
\end{tabular}

Fonte: LABRANO, 1998, p. 125-127. Elaboração: Ribeiro, 2016.

Tanto na Aladi, quanto no Mercosul e na Unasul, pode-se dizer que todos os órgãos são intergovernamentais, vez que seus poderes são limitados, assim como as suas faculdades, uma vez que os Estados Partes detém poder de veto sobre as decisões aprovadas. Ou seja, dentre os órgãos executivos não existem poderes supranacionais, como autonomia executiva, autonomia legislativa, autonomia decisória ou financeira.

Se utilizarmos o critério de repartição de poderes, entendendo o Executivo como formado por representantes dos Poderes Executivos nacionais, o Legislativo como órgãos parlamentares de natureza eletiva e o Judiciário como órgão jurisdicional ou arbitral, podem-se categorizar os organismos da seguinte forma:

Quadro 4- Organizações regionais e a natureza de seus órgãos

\begin{tabular}{|c|c|c|c|}
\hline \multirow{5}{*}{ 这 } & "EXECUTIVO" & "LEGISLATIVO" & "JUDICIÁRIO" \\
\hline & $\begin{array}{l}\text { Conselho de Ministros } \\
\text { Relacões Exteriores }\end{array}$ & & \\
\hline & $\begin{array}{llll}\text { Conferência } & \text { de } & \text { Avaliação } & \text { e } \\
\text { Convergência } & & & \end{array}$ & & \\
\hline & Comitê de Representantes & & \\
\hline & Secretaria-Geral & & \\
\hline \multirow{4}{*}{ 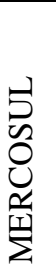 } & Conselho do Mercado Comum & \multirow{4}{*}{$\begin{array}{l}\text { Parlamento do } \\
\text { Mercosul (Parlasul) }\end{array}$} & \multirow{2}{*}{$\begin{array}{l}\text { Tribunais arbitrais ad } \\
\text { hoc }\end{array}$} \\
\hline & Grupo Mercado Comum & & \\
\hline & Comissão de Comércio & & \multirow{2}{*}{$\begin{array}{l}\text { Tribunal Permanente de } \\
\text { Revisão }\end{array}$} \\
\hline & Foro Consultivo Econômico-Social & & \\
\hline \multirow{3}{*}{$\begin{array}{l}\text { S } \\
\text { 足 } \\
\text { 号 }\end{array}$} & $\begin{array}{l}\text { Conselho de Chefas e Chefes de } \\
\text { Estado e de Governo }\end{array}$ & \multirow[t]{3}{*}{$\begin{array}{ll}\text { (Parlamento } & \text { Sul- } \\
\left.\text { Americano }^{7}\right) & \end{array}$} & \\
\hline & $\begin{array}{l}\text { Conselho de Ministras e Ministros } \\
\text { das Relações Exteriores }\end{array}$ & & \\
\hline & $\begin{array}{llll}\begin{array}{l}\text { Conselho } \\
\text { Delegados }\end{array} & \text { de } & \text { Delegadas } & \text { e }\end{array}$ & & \\
\hline
\end{tabular}

Fonte: RIBEIRO, 2012.

Constata-se, no quadro 4, que somente o Mercosul conta com um órgão parlamentar estabelecido e com um órgão de solução de controvérsias. O Artigo 17 do Tratado Constitutivo da Unasul prevê a criação do Parlamento Sul-Americano e sua

7 O Artigo 17, Tratado Constitutivo da Unasul, confirma que a sede do Parlamento será em Cochabamba/Bolívia, mas a sua criação será definida em outro protocolo. 
sede em Cochabamba, Bolívia, porém a bancada brasileira tem resistido a implementação do Parlamento da Unasul ${ }^{8}$. Em artigo transitório do Tratado Constitutivo é estabelecida a criação de uma "Comissão Especial", integrada por Membros de Parlamentos nacionais e regionais, que vai elaborar um Projeto de Protocolo Adicional a ser considerado na IV Cúpula de Chefas e Chefes de Estado e de Governo 9 .

Os desenhos institucionais supramencionados têm como resultado final os procedimentos de tomada de decisão, que serão delineados pelas estruturas por eles estabelecidos. Assim, os procedimentos políticos estruturam o desenho institucional e são por ele estruturados em um movimento que responde a conjuntura vigente. Dessa forma, os processos de tomada de decisão não são simples deliberações, mas parte de um processo de embates de interesses sociopolítico e comerciais encaminhadas por meios diplomáticos, sob a pressão dos partidos políticos e de grupos empresariais de grande presença na vida política dos países.

\section{PROCESSO DE TOMADA DE DECISÃO}

O processo de tomada de decisões é determinante para o sucesso ou o insucesso de uma organização, haja vista que ele deve refletir os interesses de seus membros, de forma a gerar resultados que são aceitáveis e vistos como legítimos por todos (Ribeiro, 2016). Na integração sul-americana, existem alguns critérios que são comuns entre os organismos analisados.

Na Aladi e no Mercosul, é necessário que todos os Estados Partes estejam presentes para que se realize uma votação. Já na Unasul, o quórum é de ao menos três quartos dos Estados Partes. Não obstante necessitar de uma maioria qualificada, a Unasul adota suas normativas mediante consenso. Para que o consenso seja alcançado, os Estados Partes, que não estavam presentes são notificados pela Secretaria-Geral para a realização de consultas. Se há a consulta aos Estados que não estavam presentes,

\footnotetext{
8 A bancada brasileira se posicionou contra a união entre o Parlamento Andino e o Parlamento do Mercosul, para criação do Parlamento da União das Nações Sul-Americanas (Unasul), pois os parlamentares compreendem que os trabalhos devem estar concentrados na consolidação do Parlamento do Mercosul e entendem que o Parlamento do Mercosul é o parlamento latino-americano (Agência Câmara, 08/10/2007).

9 A Declaração da IV Reunião Ordinária da Unasul (Georgetown, República Cooperativa de Guayana, 26/11/2010), em seu item 30, apenas exorta aos Poderes Legislativos "a consensuar o projeto definitivo de Protocolo Adicional que estabelecerá o Parlamento Sul-Americano, com miras a avançar até a convergência nesta matéria”.
} 
pode-se interpretar que as regras são adotadas mediante a "presença/ciência", ainda que a posteriori, de todos os Estados.

\section{Quadro 5- Organizações regionais e tomada de decisão}

\begin{tabular}{|l|c|c|}
\hline & TODOS "PRESENTES" & 3/4 PRESENTES \\
\hline ALADI & $\mathrm{X}$ & \\
\hline MERCOSUL & $\mathrm{X}$ & $\mathrm{X}$ \\
\hline UNASUL & $(\mathrm{X})$ & \\
\hline
\end{tabular}

Fontes: Tratado de Montevidéu de 1980, Tratado de Assunção, Protocolo de Ouro Preto e Tratado

Constitutivo da Unasul. Elaboração: Ribeiro, 2016

No Mercosul, também é adotada a regra do consenso para a tomada de decisões, ao passo que na Aladi, a regra geral é o voto afirmativo de dois terços dos Estados Partes e a exceção é a necessidade do voto afirmativo de dois terços, sem que haja voto negativo. Para esses fins, abstenção não significará voto negativo e a ausência, no momento da votação é interpretada como abstenção.

Esse quórum especial de votação se aplica a assuntos considerados mais sensíveis, tais como emendas ao TM80, e decisões que: (1) versem sobre a condução política da integração; (2) formalizem o resultado das negociações multilaterais para o estabelecimento e o aprofundamento da preferência tarifária regional; (3) levem à multilateralização dos acordos de alcance parcial; (4) adotem medidas corretivas que surjam das avaliações do andamento do processo de integração.

Pode-se perceber, ao analisar o procedimento com um olhar mais atento, que a regra de quórum mínimo (2/3) sem o voto negativo de nenhum Estado é o mesmo que um consenso. Portanto, o quórum para votação de decisões, pode ser organizado da seguinte forma:

Quadro 6- Organizações regionais e tomada de decisão

\begin{tabular}{|l|c|c|}
\hline & CONSENSO & VOTO AFIRMATIVO DE 2/3* \\
\hline ALADI & $(\mathrm{X})$ & $\mathrm{X}$ \\
\hline MERCOSUL & $\mathrm{X}$ & \\
\hline UNASUL & $\mathrm{X}$ & \\
\hline
\end{tabular}

Fontes: Tratado de Montevidéu de 1980, Tratado de Assunção, Protocolo de Ouro Preto e Tratado Constitutivo da Unasul. Elaboração: Ribeiro, 2016.

Verifica-se que há uma preocupação com a concordância dos Estados em relação às decisões. Seja por meio da presença de todos durante as votações (Aladi e Mercosul); da presença de dois terços, sendo que todos serão consultados sobre a decisão (Unasul); ou pela adoção de um consenso (Unasul e Mercosul) ou nãoexistência de voto negativo (Aladi). 
Ao se observar as regras em conjunto, da forma como elas são descritas nos tratados que a estabeleceram, verifica-se que os quóruns (presença e votação) são os mesmos. No entanto, ao fazer uso das análises acima, vê-se que a regra geral aplicável a todos os organismos é o consenso, com a participação presencial de todos os Estados.

\section{Quadro 7- Organizações regionais e tomada de decisões}

\begin{tabular}{|l|c|c|c|}
\hline \multicolumn{1}{|c|}{ QUÓRUM } & ALADI & MERCOSUL & UNASUL \\
\hline Consenso com "presença" de todos & $(\mathrm{X})$ & $\mathrm{X}$ & $(\mathrm{X})$ \\
\hline Consenso com presença de 3/4 & & & $\mathrm{X}$ \\
\hline Afirmativo de 2/3 com presença de todos & $\mathrm{X}$ & & \\
\hline $\begin{array}{l}\text { Afirmativo de } 2 / 3 \text { com presença de todos sem } \\
\text { voto negativo }\end{array}$ & $\mathrm{X}$ & & \\
\hline
\end{tabular}

Fontes: Tratado de Montevidéu de 1980, Tratado de Assunção, Protocolo de Ouro Preto e Tratado Constitutivo da Unasul. Elaboração: Ribeiro, 2016.

Para além da tomada de decisões de cunho técnico-político, sem desconsiderar as influências sociopolíticas, os desenhos institucionais também delimitam e delineiam o sistema de solução de controvérsias entre os seus membros. São essas estruturas de solução de controvérsias que permitem uma relação igualitária e soberana entre os Estados-partes.

\section{SOLUÇÃO DE CONTROVÉRSIAS}

Os sistemas de solução de controvérsias da Aladi, do Mercosul e da Unasul têm em comum a necessidade (ou a possibilidade) de negociações diretas (também chamadas de consultas) entre os Estados Partes. Outro ponto de convergência de procedimento das três instituições, é que no insucesso das negociações entre as Partes da controvérsia, pode-se solicitar a um órgão do bloco que faça os bons ofícios (nestes casos, o Comitê de Representantes, o Grupo Mercado Comum ou o Conselho de Delegadas e Delegados). No caso da Aladi, essas são as duas possibilidades aventadas. $\mathrm{Na}$ Unasul, pode-se recorrer a mais uma instância, que se encarregará de realizar a mediação (Conselho de Ministras e Ministros das Relações Exteriores).

O Mercosul, após as negociações diretas e a mediação do GMC (não obrigatória para prosseguir), os Estados podem submeter sua controvérsia a um tribunal arbitral ad hoc ou diretamente ao Tribunal Permanente de Revisão (TPR). No caso de opção pela solução arbitral ad hoc, o TPR pode ser acionado em sede de recurso.

Podem-se assinalar como pontos em comum entre as três instituições, a mediação dos Ministérios das Relações Exteriores (por meio de órgãos da estrutura institucional) no Mercosul e na Unasul, e de representantes dos Estados Partes na Aladi 
e na Unasul. A única divergência que existe entre os modelos é a existência de órgãos especializados para solução de controvérsias no Mercosul, enquanto os demais não os possuem. De forma sistematizada, essas informações podem se apresentar da seguinte forma:

\begin{tabular}{|c|l|l|}
\hline \multicolumn{2}{|c}{ Quadro 8 } \\
\hline \multirow{4}{*}{ OLADI } & \multicolumn{1}{|c|}{ Cõo } & \multicolumn{1}{c|}{ COMPOSIÇÃO } \\
\hline \multirow{4}{*}{ MERCOSUL } & Consultas & Estados envolvidos na controvérsia \\
\cline { 2 - 3 } & Comitê de Representantes & Representantes dos Estados Partes \\
\cline { 2 - 3 } & Negociações Diretas & Estados envolvidos na controvérsia \\
\cline { 2 - 3 } & Grupo Mercado Comum & $\begin{array}{l}\text { Ministérios das Relações Exteriores, } \\
\text { Ministros de Economia da Economia ou } \\
\text { do Banco Central }\end{array}$ \\
\cline { 2 - 3 } & $\begin{array}{l}\text { Tribunal arbitral ad hoc } \\
\text { Revisão }\end{array}$ & $\begin{array}{l}\text { Árbitros selecionados de uma lista, } \\
\text { indicados pelos Estados }\end{array}$ \\
\hline \multirow{5}{*}{ UNASUL } & Negociações Diretas & $\begin{array}{l}\text { Árbitros integrantes do TPR, indicados } \\
\text { pelos Estados }\end{array}$ \\
\cline { 2 - 3 } & $\begin{array}{l}\text { Conselho de Delegadas e } \\
\text { Delegados }\end{array}$ & Estados envolvidos na controvérsia \\
\cline { 2 - 3 } & $\begin{array}{l}\text { Conselho de Ministras e } \\
\text { Ministros das Relações } \\
\text { Exteriores }\end{array}$ & Ministros das Relações Exteriores \\
\hline
\end{tabular}

Fontes: Tratado de Montevidéu de 1980, Tratado de Assunção, Protocolo de Ouro Preto, Protocolo de Olivos e Tratado Constitutivo da Unasul. Elaboração: Ribeiro, 2016.

Cabe apontar que Keohane, Andrew Moravcsik e Anne-Marie Slaughter (2002, p. 163) indicam três características da resolução internacional de controvérsias que conformariam dois tipos ideais: (1) independência; (2) acesso; (3) e inserção. Nesse sentido, pode-se classificar os sistemas de solução de controvérsias dos organismos regionais da seguinte forma:

\begin{tabular}{|c|l|c|c|c|}
\multicolumn{1}{|c|}{ Quadro 09 } \\
\hline \multirow{3}{*}{ ALADI } & \multicolumn{1}{|c|}{ ÓRGÃO } & INDEPENDÊNCIA & ACESSO & INSERÇÃO \\
\hline \multirow{4}{*}{ MERCOSUL } & Consultas & Baixa & Alto & Baixa \\
\cline { 2 - 5 } & $\begin{array}{l}\text { Comitê de } \\
\text { Representantes }\end{array}$ & Baixa & Alto & Baixa \\
\cline { 2 - 5 } & Negociações Diretas & Baixa & Alto & Baixa \\
\cline { 2 - 5 } & Trupo Mercado Comum & Baixa & Alto & Baixa \\
\cline { 2 - 5 } & Tribunal arbitral ad hoc & Media & Alto & Média \\
\hline
\end{tabular}




\begin{tabular}{|c|c|c|c|c|}
\hline & $\begin{array}{l}\text { Tribunal Permanente de } \\
\text { Revisão }\end{array}$ & Média & Alto & Média \\
\hline \multirow[b]{3}{*}{ UNASUL } & Negociações Diretas & Baixa & Alto & Baixa \\
\hline & $\begin{array}{l}\text { Conselho de Delegadas } \\
\text { e Delegados }\end{array}$ & Baixa & Alto & Baixa \\
\hline & $\begin{array}{l}\text { Conselho de Ministras e } \\
\text { Ministros das Relações } \\
\text { Exteriores }\end{array}$ & Baixa & Médio & Baixa \\
\hline
\end{tabular}

Fontes: Keohane; Moravcsik; Slaughter, 2002, Tratado de Montevidéu de 1980, Tratado de Assunção, Protocolo de Ouro Preto, Protocolo de Olivos e Tratado Constitutivo da Unasul. Elaboração: Ribeiro, 2016.

No quadro acima, a independência dos organismos foi classificada como baixa, haja vista que são os próprios Estados ou seus representantes que devem promover a resolução do conflito. A classificação média se deu por serem órgãos da estrutura institucional com competência exclusiva para o assunto, no entanto, a seleção dos árbitros é realizada mediante indicação dos Estados, caso a caso, ou para mandatos, o que poderia vir a comprometer a independência dos árbitros.

O acesso aos meios disponíveis é alto, com exceção do acesso ao Conselho de Ministras e Ministros das Relações Exteriores, pois para que a controvérsia chegue nesse órgão é necessário passar por duas etapas obrigatórias anteriores.

A inserção baixa, como última característica, foi atribuída a quase todos os procedimentos, tendo em vista que não há penalidade prevista para descumprimento de algum acordo. A inserção média foi aplicada aos mecanismos arbitrais, considerando que há possibilidade de aplicação de medidas compensatórias diante o não cumprimento ou do cumprimento parcial dos laudos arbitrais.

O mencionados autores (Keohane et al, 2002, p. 163) também classificam as estruturas entre: (1) resolução de controvérsias interestatais; e (2) resolução de controvérsias transnacionais. Nesse sentido, podemos organizá-las da seguinte forma:

Quadro 10

\begin{tabular}{|c|c|c|}
\hline & $\begin{array}{l}\text { RESOLUÇÃO DE } \\
\text { CONTROVÉRSIAS } \\
\text { INTERESTATAIS }\end{array}$ & $\begin{array}{c}\text { RESOLUÇÃO DE } \\
\text { CONTROVÉRSIAS } \\
\text { TRANSNACIONAIS }\end{array}$ \\
\hline \multirow[b]{2}{*}{ ALADI } & Consultas & \\
\hline & Comitê de Representantes & \\
\hline \multirow[b]{2}{*}{ MERCOSUL } & Negociações Direta & Tribunal arbitral ad hoc \\
\hline & Grupo Mercado Comum & Tribunal Permanente de Revisão \\
\hline \multirow{3}{*}{ UNASUL } & Negociações Diretas & \\
\hline & Conselho de Delegadas e Delegados & \\
\hline & $\begin{array}{l}\text { Conselho de Ministras e Ministros } \\
\text { das Relações Exteriores }\end{array}$ & \\
\hline
\end{tabular}


Fontes: Tratado de Montevidéu de 1980, Tratado de Assunção, Protocolo de Ouro Preto, Protocolo de Olivos e Tratado Constitutivo da Unasul. Elaboração: Ribeiro, 2016.

Nota-se, então, que há uma preponderância da resolução de controvérsias interestatal, na medida em que os órgãos responsáveis pela resolução dos conflitos são formados por representantes do Poder Executivo dos Estados Partes do organismo de integração. Apenas o Mercosul possui um órgão arbitral formado por especialistas escolhidos de uma lista de árbitros, previamente indicada pelos Estados. Pode-se, portanto, perceber que há um controle grande dos Estados nesses processos.

\section{CONSIDERAÇÕES FINAIS}

Este artigo tem como propósito estabelecer comparações entre Aladi, Mercosul e Unasul, instituições regionais de integração regional sul-americanas, a partir da aferição dos níveis de democratização que cada instituição construiu, considerando os interesses comuns e divergente entre os Estados Partes, das organizações civis e grupos empresariais, que delas participam. Entre os desafios que o texto enfrenta, podem-se listar como principais, a falta de transparência nas deliberações e na difusão de informação sobre os acordos e proposições em tramitação nos diversos níveis das estruturas de poder, e o déficit de democracia, ou a falta de espaços de intervenção da sociedade civil, em especial das organizações e movimentos populares com pouco poder de representação política.

Os pesquisadores têm investigado a conformação de espaços políticos de tensão e a existência de momentos pendulares de aproximação e afastamento entre os Estados sul-americanos, e entre estes e as suas respectivas sociedades civis, motivados, principal, mas não exclusivamente, pelo arranjo e rearranjo das estratégias econômicas de desenvolvimento e das forças políticas internas em cada país e seu alinhamento ideológico em relação aos Estados Unidos, para a construção dos projetos de integração sul-americana. No primeiro capítulo, buscou-se explorar esses movimentos pendulares, em que os fatos, eventos e contextos foram descritos no sentido de compor o histórico da formação política e socioeconômica do processo de integração sul-americano.

Ainda que a criação de uma instituição não tenha decorrido diretamente de outra, embora cada uma se origine de uma base teórica e de um contexto político diferenciado, percebe-se um desdobramento que implica em um refinamento no desempenho, funcionamento e composição nas funções, a fim de se aproximar da 
realidade latino-americana. Pode-se atribuir a esse aprimoramento a evolução do contexto político-econômico, que permitiu a oportunidade dos atores governamentais a superar as desconfianças e os óbices para o aprofundamento da integração. Assim, foram se constituindo as instituições de integração, que por aproveitamento da herança das experiências anteriores, foram conquistando reconhecimento e legitimidade para avançar na pauta regional.

Buscou-se acentuar algumas observações, ainda que não exaustivas sobre os órgãos que compõem as três instituições de integração regional (Aladi, Mercosul e Unasul), os processos de integração regional ao serem conformados e fundamentados em regras e normas gerais, identificando suas características e peculiaridades. Tal exercício foi satisfatório para identificar traços comuns e divergentes na estrutura institucional dos três organismos regionais.

Quando o foco é a convergência entre as instituições regionais, observada por meio da análise comparativa, o que se nota é a unicidade do processo integracionista sul-americano. Essa afirmação se confirma na medida em que os avanços institucionais se revelaram como estratégia adotada pela região para uma integração defensiva e específica. Os principais pontos em comum encontradas no desenho institucional dos modelos sul-americanos de integração observados são: (1) intergovernabilidade como paradigma; (2) adoção do consenso com a presença de todos os Estados Partes, como quórum, para tomada de decisões; (3) atuação direta dos Ministérios das Relações Exteriores dos Estados Partes na definição da agenda e no policy-making dos organismos; (4) hegemonia dos órgãos executivos; (5) inexistência de órgãos judiciais strictu sensu; (6) negociação direta e a mediação por representantes dos Estados Partes como procedimento de solução de controvérsias; (7) pouco espaço para a participação e incidência da sociedade civil.

O caráter intergovernamental do processo de integração sul-americana tem sido adotado pelas organizações ao longo do tempo, mesmo que as instituições regionais tenham evoluído em suas regras e procedimentos de tomada de decisão. O desenho da estrutura institucional tem propiciado o controle da agenda e das decisões pelos Estados, colocando em pé de igualdade os órgãos estatais de maior e menor poder relativo. Nesse sentido, percebe-se que a intenção dos legisladores é manter o papel e o poder do Estado no âmbito regional, não renunciando de exercer sua soberania. A estrutura tem conferido aos Estados a autonomia para colocar na agenda dos blocos regionais os 
assuntos de interesse direto, sem que haja um órgão autônomo para realizar esse papel. Assim, a definição das políticas regionais está a cargo dos próprios países.

Apesar de os textos dos tratados constitutivos dos três organismos definirem de forma diferente o formato para a tomada de decisões, que se baseia na anuência dos Estados Parte, sem que haja oposição, para que se aprove determinada proposição. Ao atribuir um voto para cada Estado e adotar a regra do consenso, o modelo impede que a instituição regional, por si só, determine ou oriente a direção da integração, em oposição aos interesses dos Estados. Ou seja, a instituição não está dotada de autonomia, mas consubstancia-se em foro de negociação interestatal. Pode-se dizer que as decisões adotadas pelos organismos em análise, da mesma forma que os tratados internacionais latu sensu, passam por um processo de negociação e assinatura pelo poder Executivos e ratificação por parte dos poderes legislativos.

Os órgãos de decisão dos três organismos regionais em tela são compostos por representantes dos Estados Parte, em especial do Poder Executivo. A supremacia do Poder Executivo é constatada ao se verificar que os órgãos com poder decisório são formados por Chefes de Estado ou pelos Ministérios das Relações Exteriores (Ribeiro, 2010). Além do mais, a adoção do consenso no processo de tomada de decisões, as regras legitimadas no âmbito dos modelos de integração necessitam, via de regra, passar pelo processo de internalização aos ordenamentos jurídicos dos Estados Parte, o que corrobora a percepção de que não se trata de organismos independentes, mas de foros de negociação, dotados de uma estrutura institucional fixa.

No que tange ao sistema de solução de controvérsias verifica-se que nenhum dos órgãos jurisdicionais strictu sensu detém o poder de imposição de cumprimento das suas sentenças. Ademais, as três instituições empregam como forma de solução de controvérsias as negociações diretas, seguidas de mediação por um órgão regional. Esse órgão mediador, conforme visto, é formado em sua totalidade por representantes dos Poderes Executivos dos Estados Parte, em especial por membros dos Ministérios das Relações Exteriores. Pode-se dizer, portanto, que tanto as negociações diretas quanto as mediatizadas são realizadas diretamente pelos próprios Estados. No caso específico do Mercosul, os Estados detêm a possibilidade de recorrer a dois foros arbitrais, compostos por árbitros nacionais dos Estados Partes, indicados previamente para a conformação de uma lista. De toda sorte, a indicação e escolha dos árbitros também é realizada pelos próprios Estados. 
Assim, são os Estados os verdadeiros atores protagonistas do processo de integração regional, retirando, por meio do desenho estrutural das instituições, como por meios regimentais que obstaculizaram a participação das organizações e movimentos sociais tanto nas áreas decisórias, como nas de proposição de políticas regionais. A falta de informação e propagação das funções e importância da integração para os povos sulamericanos, não permitiu a emergência de uma consciência supranacional, que poderia alavancar a criação de espaços democráticos nas instituições e, inclusive, democratizálas. Assinala-se que apesar das intenções contidas nos instrumentos de integração, não se logrou ultrapassar o limite uma união aduaneira imperfeita como nível de integração de fato. Tanto a Aladi quanto o Mercosul encontram-se em um baixo nível de integração econômica, sem ter aberto grandes áreas de participação da sociedade civil.

Conforme apontado, os Estados sul-americanos, diferente dos europeus, seguem um modelo próprio de integração, sejam eles de viés mais comercial (Aladi e Mercosul) ou político (Unasul). O contexto internacional, no qual os Estados nacionais se ambientavam quando da assinatura dos tratados constitutivos (Aladi, Mercosul e Unasul), eram bastante distintos e as teorias econômicas vigentes e influenciaram na opção dos respectivos modelos institucionais. Em adição, o corte ideológico dos governos dos Estados Parte também foi fator determinante no formato de integração adotado. Os governos mais conservadores preferiram uma integração meramente econômica, ao passo que os que se posicionam no campo progressista elegeram uma integração econômico-social. Isso não quer dizer que a hegemonia dos Estados progressistas aumentou significativamente a participação social ou houve um estímulo governamental expressivo para integrar os grupos sociais nos processos de integração. As Cúpulas Sociais do Mercosul, por exemplo, foram importantes, mas não promoveram alterações substantivas nas pautas regionais e, em algumas edições, a qualidade e a autonomia das organizações sociais foram questionadas.

A formação de organismos supranacionais tem em comum contradições que só podem ser superadas a partir das experiências e dos desafios que os Estados Parte vão encontrado e superando, durante o processo histórico. Os organismos de integração sulamericanos apresentam como ponto em comum a necessidade de se aproximarem e estabelecerem relações com vistas a superação de divergências e suspeitas históricas, diante da ameaça acelerada da globalização econômica protagonizada pelos países centrais. 
Os Estados têm expressado dois discursos antagônicos: um discurso oficial, no qual compartilham valores, antecedentes históricos, perspectivas e interesses solidários; e outro, no qual expressam certo grau de desconfiança - basta ver o desenho das instituições que priorizam o controle dos Estados em detrimento da criação de uma cultura organizacional supranacional. O modelo sul-americano de integração apresentase como um modelo pensado e executado para não integrar, na medida em que foi idealizado para permitir que os Estados controlem a velocidade e o aprofundamento do processo de integração, a partir de suas estratégias geoeconômicas. Ao apresentar as similitudes e as diferenças das três instituições (Aladi, Mercosul e Unasul) em seus diversos campos de estruturação de poder, se possibilitou a aferição dos níveis de democratização que cada instituição construiu na solidão dos interesses estatais.

\section{REFERÊNCIAS}

ALMEIDA, Paulo Roberto. O Mercosul no contexto regional e internacional. São Paulo: Aduaneiras, 1993.

A integração na América do Sul em perspectiva histórica: um balanço. Espaço Sophia, Tomazina, PR, ano 2, n. 23, p. 1-17, 2009.BETHELL, Leslie (organização). História da América Latina: A América Latina após 1930: Estado e Política. São Paulo: Editora da Universidade de São Paulo, 2009. História da América Latina: (vol. 7). 668p.

BIELSCHOWSKY, Ricardo, org. O regionalismo aberto na américa latina e no caribe: a integração econômica a serviço da transformação produtiva com equidade. Documento coordenado por Gert Rosenthal (p.937-958). In. Cinquenta anos de pensamento na CEPAL. Volume 2. Editora Record, Rio de Janeiro, 2000.

BRAGA, Márcio B. Integração econômica regional na América Latina: uma interpretação das contribuições da CEPAL. Ind. Econ. FEE, Porto Alegre, v. 29, n. 4, p. 200-220, fev. 2002. Disponível em: < http://revistas.fee.tche.br/index.php/indicadores/article/viewFile/1345/1711>. Acesso em: 12 mar. 2017.

BRESSER-PEREIRA, L. C. Estado e mercado no novo desenvolvimentismo. Nueva Sociedad, Bogotá, n. 210, jul./ago. 2007.

BRESSER-PEREIRA, L.C. A nova esquerda: uma visão a partir do sul. Revista Filosofia Politica, nova série, vol.6, 2000: 144-178. ; NAKANO, Yoshiaki. Uma estratégia de desenvolvimento com estabilidade. Revista de Economia Política, v. 21, n. 2, p. 146-177, jul. 2002.

BRESSER-PEREIRA, L.C. Uma interpretação da América Latina: a crise do estado Novos. Estudos CEBRAP, 37, Novembro 1993: 37- 57.

CERVO, Amado Luiz. Relações internacionais da América Latina: de 1930 aos nossos dias. 3ed. rev. e atual. São Paulo: Saraiva: Instituto Brasileiro de Relações Internacionais, 2013. 
Elisa Ribeiro

Edelcio Vigna
Cadernos Prolam/USP, v.16, n.31, p.30-58, jul./dez.2017

DOI: 10.11606/issn.1676-6288.prolam.2017.133185

CORAZZA, Gentil. "Regionalismo aberto" da CEPAL e a inserção da América Latina na globalização. Ensaios FEE, Porto Alegre, v. 27, n. 1, p. 135-152, maio 2006.

DATHEIN, Ricardo. A Integração Latino-Americana sob a Perspectiva do Desenvolvimento Econômico. Professor Adjunto do Departamento de Ciências Econômicas e do Programa de Pós-Graduação em Economia da FCE/UFRGS. https://www.ufrgs.br/fce/wp-content/uploads/2015/02/TD17_2005_dathein.pd

DEVÉS VALDÉS, Eduardo. El pensamiento latinoamericano en el siglo XX: desde la CEPAL al neoliberalismo 1950-1990. $1^{\text {a }}$ ed. Buenos Aires: Biblos, 2003. v.2.

DREYZIN DE KLOR, Adriana. El Mercosur. Generador de una nueva fuente de derecho internacional privado. Buenos Aires: Zavalia, 1997.

Sistema Político-Institucional del Mercosur. Revista de Derecho Privado y Comunitário. Santa Fé: Rubinzal Culzoni Editores, 2005.

G1.GLOBO. Ao lado de Macri, Temer defende fim de 'obstáculos ao comércio' no Mercosul. Luciana Amaral, G1, Brasília, 07/02/2017.

http://g1.globo.com/politica/noticia/ao-lado-de-macri-temer-defende-fim-de-obstaculosao-comercio-no-mercosul.ghtml

KEOHANE, Robert O.; MORAVCSIK, Andrew; SLAUGHTER, Anne-Marie. (2000). Legalized dispute resolution: interstate and transnational. In: KEOHANE, Robert O. Power and Governance in a Partially Globalized World. London; New York: Routledge, 2002. p. 152-189.

LABRANO, Roberto. Mercosur: Integración y Derecho. Buenos Aires: Cuidad Argentina, 1998.

MARTINS, Carlos Eduardo. Globalização, dependência e neoliberalismo na América Latina. São Paulo: Boitempo, 2011.

O'SUlliVAN, John. Annexation (1845). United States Magazine and Democratic Review, 17, no. 1 (July-August 1845): 5-10.

PADRÓS, S. P. Terror de Estado e Segurança Nacional - Uruguai (1968-1985): do Pachecato à Ditadura Civil-Militar. UFGRS, Instituto de Filosofia e Ciências Humanas, Programa de Pós-Graduação em História, Porto Alegre, 2005.

PECEQUILO, Cristina Soreanu; CARMO, Corival Alves do. O Brasil e a América do Sul: relações regionais e globais. Rio de Janeiro, RJ: Alta Books, 2015.

PREBISCH, R. El Desarrollo Económico De La América Latina y Algunos De Sus Principales Problemas. Desarrollo Económico, Vol. 26, No. 103.Out. - Dez., 1986.

RAICHELIS, Raquel. A questão do neodesenvolvimentismo e as políticas públicas. Entrevista especial com Rodrigo Castelo. PUC-SP Realizada em novembro de 2013. Entrevista publicada originalmente na Revista de Políticas Públicas, do Programa de Pós-Graduação em Políticas Públicas da Universidade Federal do Maranhão, São Luís, v. 17, n. 2, p. 389-393, jul./ dez. 2013. Serv . Soc. Soc., São Paulo, n. 119, p. 583-591, jul./set. 2014.

RIBEIRO, Elisa S. Mercosul: Sobre Democracia e Instituições. Editora CRV, Curitiba: 2012.

Instituições e Integração Regional na América do Sul: Uma Análise Comparativa entre ALADI, Mercosul e Unasul. Tese apresentada como requisito para 
Elisa Ribeiro

Edelcio Vigna
Cadernos Prolam/USP, v.16, n.31, p.30-58, jul./dez.2017 DOI: 10.11606/issn.1676-6288.prolam.2017.133185

conclusão do curso de Doutorado em Ciências Sociais na Universidade de Brasília. Brasília, 2016.

PINCHEMEL, Felipe. Paradigmas da atuação brasileira no Mercosul. Revista Universitas: Relações Internacionais, Brasília, Vol. 9, No 1, 2011.

SINGER, A.. Esquerda e direita no eleitorado brasileiro: a identificação ideológica nas disputas presidenciais de 1989 e 1994. São Paulo: USP, 2002.

TAROUCO, Gabriela S, e Madeira, Rafael M. Partidos, programas e o debate sobre Esquerda e direita no Brasil. Revista de Sociologia e Política, v. 21, nº 45: 149-165 mar. 2013.

VENTURA, Deisy. As assimetrias entre o MERCOSUL e a União Europeia. Os desafios de uma associação inter-regional. Manole: Barueri, 2003.

Recebido em 26/05/2017. Aceito em 02/04/2018. Publicado em 02/04/2018. 